\title{
The Economic Portrait of Mamluk Dynasty of Egypt; History and Thought
}

\author{
Havis Aravik ${ }^{1}$, Fakhry Zamzam ${ }^{2}$, Ahmad Tohir ${ }^{3}$ \\ 1,3STEBIS IGM Palembang, 2IGM University Palembag, \\ doi) https://doi.org/10.32507/mizan.v4i1.642
}

\begin{abstract}
This article discusses the economic portrait during the Mamluk dynasty in Egypt; The history and thought by aiming to find out how the Islamic economy during the Mamluk dynasty in Egypt was. This research used qualitative research based on the library (library research) with a descriptive qualitative approach and technical analysis and also content analysis. The results of this study indicated that the Islamic economy during the Mamluk Dynasty advanced with various policies such as the governmental system that was the military oligarchic not monarchic, rewarding for scientists and academics, establishing trade relations with foreign countries, free-market policies to farmers, navy resilience, and the effective use of waqf property. Meanwhile, the decline was caused by a prolonged economic crisis, the sultan's lifestyle, corruption and economic monopoly, attacks by other nations, and the bad behavior of the sultans.
\end{abstract}

Keywords: Mamluk Dynasty, Advancement, Decline, Economy

\begin{abstract}
Abstrak.
Artikel ini membahas potret ekonomi selama dinasti Mamluk di Mesir; Sejarah dan pemikiran dengan bertujuan untuk mengetahui bagaimana ekonomi Islam selama dinasti Mamluk di Mesir. Penelitian ini menggunakan penelitian kualitatif yang berbasis pada perpustakaan (library research) dengan pendekatan kualitatif deskriptif dan analisis teknis serta analisis isi. Hasil penelitian ini menunjukkan bahwa ekonomi Islam selama Dinasti Mamluk maju dengan berbagai kebijakan seperti sistem pemerintahan yang oligarki militer tidak monarkis, memberi imbalan bagi para ilmuwan dan akademisi, membangun hubungan perdagangan dengan negara-negara asing, kebijakan pasar bebas untuk petani, ketahanan angkatan laut, dan penggunaan efektif properti wakaf. Sementara itu, penurunan tersebut disebabkan oleh krisis ekonomi yang berkepanjangan, gaya hidup sultan, korupsi dan monopoli ekonomi, serangan oleh negara-negara lain, dan perilaku buruk para sultan. Kata kunci: Dinasti Mamluk, Kemajuan, Penurunan, Ekonomi
\end{abstract}

* Manuscript accepted: January 12, 2020, revised: March 15, 2020, approved for publication: June 4, 2020.

${ }^{1}$ Havis Aravik is a lecturer at IGM STEBIS Palembang. E-mail: havis@stebisigm.ac.id.

${ }^{2}$ Fakhry Zamzam is a lecturer at IGM University Palembang. E-mail: fakhry@uigm.ac.id

${ }^{3}$ Ahmad Tohir is a lecturer at IGM STEBIS Palembang. Email: tohir@stebisigm.ac.id. 


\section{A. INTRODUCTION}

Islam once created the great civilizations both in the East and West in various fields of life namely economic, political, social, cultural, and so forth. In the East, for example, standing proudly the Abbasid dynasty centered in Baghdad, Iraq with the Bait al-hikmah as a crater of the leading intellectual that produced various works that inspired the world to be a representation of the great civilizations in the East. In the West, there was the Umayyad dynasty in Andalusia, Spain with the University of Cordova and the University of al-Hambra of Granada as the center of knowledge that became the reference for Europeans to comprehend the world. Amid these two civilizations, an Islamic civilization emerged in Egypt, although it was not as famous as Baghdad and Andalusia, its contribution was quite large for the glory of Islam.

Precisely the interesting thing of Islamic civilization in Egypt was not built by the great caliphs of blue blood descendants, but it was built by slave troops that raised by the caliphs and they succeeded in establishing a dynasty called the Mamluk Dynasty. Even when Baghdad as the center of Eastern civilization was completely attacked and destroyed in the hands of Mongol army under the command of Hulagu Khan and Genghis Khan and Andalusia as the center of Western civilization was devastated in the hands of Christian Crusaders, Egypt as part of Islamic civilization remained firmly standing and could be saved not only from the onslaught of the Mongol army but also the Crusaders and it managed to drive them all away before touching Egypt. All of that thanks to the greatness of the Mamluk sultans who were once slaves who were kept by the caliphs both Abbasid and Umayyad Caliphate.

Because of those reasons, this article will discuss the actions of the Mamluk Dynasty, especially in economic management. This is important to be studied because good economic development largely determines the strength of a dynasty. While in the case of the Mamluk dynasty, various caliph policies in economic development should be explored and studied further to be implemented in contemporary life.

\section{B. RESEARCH METHODOLOGY}

This research uses normative juridical research type. Normative juridical writing is library research conducted through secondary material. This research uses invitations (sculpture approach), concept approach, and comparative approach (comparative approach). The data source as a reference for this research uses a literature study.

\section{ANALYSIS AND DISCUSSION}

\section{The Emergence of Background}

The Mamluk Dynasty was a regime controlled by a slave army. The word Mamluk means slave or servant who was bought and educated intentionally to become a soldier and government employee. The Mamluk Sultans in Egypt were purchasing slaves from Turkey and Circassians who were bought by the Ayyubiah Sultan, 
Najmud-Din who then used them as his bodyguards. Therefore, the Mamluks were initially soldiers who had a very strong army motivation that was able to withstand the Mongol attacks and drive out the Crusaders who had long colonized the Sham sea coast. $^{4}$

According to Dedi Supriyadi the Mamluk Dynasty was a dynasty founded by slaves. They were originally people who were held captive by the Ayyubid dynasty as slaves, then they were trained as soldiers. They were placed in separate groups that were separated from the community. By the last Ayyubid ruler, Al-Malik al-Saleh, they were made as guards to ensure the continuity of his power. ${ }^{5}$ The Mamluk dynasty ruled in Egypt for a very long time, adorning the important records in Islamic history from 1249-1517 AD. After al-Ayyubi died, Islamic civilization experienced a vacuum. However, in the end, it could be saved from the cruelty of the Mongols.

Historically, before there was the Mamluk Dynasty, there was an ambition to have a female Sultan of Mamluk named Syajarat Ad-Durr, the wife of Ayubbi Dynasty Sultan, al-Malikus Saleh Najmuddin Ayyub. Syajarat Ad-Durr took away the power after her husband died in a battle against Luis IX's forces in Dimyati, Egypt. The crown prince, al-Malik al-Mu'azzam Turanshah, was in Syam. To keep the vigor of the Islamic forces to stay on fire and persistent, the wife hid the news of her husband's death. After Turanshah arrived in Egypt to ascend the throne as a legitimate heir, he was killed by the followers of Syajarat ad-Durr who had conspired with mamluk Baybars and Aybak. ${ }^{6}$

Finally, with the support of the Mamluk leaders, Syajar could have full power as Sultan for about three months and 80 days - because in some regions, especially in Syria, there was the turmoil of opposition to him. To ease tensions in some areas, the Abbasid caliph - as the ruler and supreme leader of the Muslims - gave a warning that the authorities in Egypt should be men, not women. Syajar was unable to refuse the caliph's order, and finally, she decided to marry his successor Sultan to rule behind the scenes. Syajar's new husband is Sultan Izzudin Aybak, one of the late Mamluk of her husband who officially became the first Sultan of the Mamluk Bahri Dynasty with the title of al-Malik al-Mu'iz. Izz al-Din Aybak al-Jawshangir al-Turkmani al-Salihi.7

The Mamluk Dynasty was generally divided into two parts, the Mamluk Bahri from Turkish slaves and Mongols and the Mamluk Burji from Circassian slaves. The achievements of the Mamluk Bahri were more prominent than the Mamluk Burji. Here are some famous Sultan of the Mamluk dynasty with various policies they made that was able to create various advances for Islamic civilization;

\footnotetext{
${ }^{4}$ Fadlil Munawwar Manshur, “Dinasti Mamluk dan Perang Salib; Perspektif Historis”, Seminar Internasional Tentang Timur Tengah, Universitas Gadjah Mada, Keluarga Alumni Gadjah Mada (Kagama) dan Departemen Luar Negeri Republik Indonesia, Yogyakarta, 25-26 Maret 2008, h. 4.

${ }^{5}$ Dedi Supriyadi, Sejarah Peradaban Islam, Bandung: Pustaka Setia, 2008, h. 236.

${ }^{6}$ Denise Aigle, "Legitimizing A Low-Born, Regicide Monarch: The Case of The Mamluk Sultan Baybars and The Ilkhans in The Thirteenth Century", Abstracta Iranica, Volume 32-33, 2013, h. 2.

${ }^{7}$ Dedi Supriyadi, Sejarah Peradaban Islam, Bandung: Pustaka Setia, 2008, h. 237.
} 


\section{a. Aybak or Izuddin Aybak bin Abdullah Shalihi (1250-1258)}

Izuddin Aybak was the first sultan of the Mamluk Dynasty in Egypt and Sham. Initially, he was a slave owned by sultan Malik ash-Saleh Najmuddin, from the Ayyubid Dynasty, known as Aybak al-Turkmani. His job was as Jashnkir (food and beverage taster) of the sultan, with the rank of Khawanja (Sultan's accountant), who was subsequently appointed as commander of the sultan's escort forces. Aybak became a Sultan after he succeeded in getting rid of the crown prince of the Ayyubid dynasty Turanshah in $648 \mathrm{H} / 1250 \mathrm{AD}$ and the Mamluk Bahriyah dynasty, which ruled in 648 H-784 H / 1250 M-1382 AD After becoming Sultan, the policies carried out by Aybak were more in fixing the empire's internal and trying to banish threats that come from the outside.

\section{b. Al-Muzhaffar Syafruddin Qutuz}

The death of Sultan Aybak caused upheaval among the mamluk figures. With Aybak's death, there were still two influential figures among them, Mudhaffar Qutuz and Baybars. Therefore, the two Mamluk figures began to fight for influence. However, Aybak's sucessor who was agreed was his son, Nuruddin Manshur Ali, who was still relatively young. As it turned out, Sultan Manshur was unable to run the government, so his governor, Qutuz, was appointed as a co-ruler.87 Qutuz saw that SyajaratudDur's existence as a strong man standing behind Manshur was quite dangerous. With Aybak assassination he had committed as the reason, then in $657 \mathrm{AH} / 1259$ AD Sultan Manshur was arrested and sentenced to death. Previously, he was forced to put down his position so that Qutuz ruled. Thus, Qutuz was officially appointed as the third sultan of the Mamluk Dynasty.

When Qutuz ascended the throne, the mamluk figure who became his best friend when he was pioneering his power, Baybars returned to Egypt after committing seclusion because of different views with Sultan Izuddin Aybak. Baybars's arrival in Egypt was welcomed by Qutuz, even the sultan appointed him as the commander of the war. At that moment, Mongol forces who had destroyed the Abbasid Daula came, they began to move and were ready to destroy Egypt. Sultan Qutuz with the help of his warlord, Baybars was ready to confront him so that there was a fierce war in Ain Jalut (Egypt) on 658 Hijri / September 3rd, 1260 AD. In that war, Mamluk troops led by Baybars managed to defeat the Mongols. The victory was able to regain the confidence of Muslims that their strength was still there. Besides, with this victory, one of the most important centers of Islamic civilization, the city of Cairo in particular, or even Egypt, in general, can be saved from the Mongol attack. This is the greatest achievement Qutuz had contributed to Muslims.

\section{c. Muhammad Ruknuddin Baybars,}

Baybars was the famous Mamluk sultan and played an important role in the formation of the Mamluk Dynasty. He was known as a mighty warlord and capable statesman. He was not only able to drive the Mongol troops out of Egypt, But he was 
also able to ravage the crusaders along the Mediterranean, the Assassins in the mountains of Syria, and Cyrenia. ${ }^{8}$

Sultan Baybars knew that Muslims in Egypt who were predominantly Sunni wanted their sultanate to get the religious endorsement from the caliph. For this reason, he did bai'at to Muntashir, one of the caliphs of the descendants of Abbas who managed to escape to Syria, when Hulagu Khan destroyed Baghdad in 1258 AD.

In the diplomatic field, Baybars established relations with Constantinople and Sicily. Meanwhile, in the economic field, Baybars opened trade routes with Italy and France through expanding the trade routes that had been pioneered by the Fatimid dynasty in Egypt before, as well as building various important infrastructures in Egypt. ${ }^{9}$ Sultan Baybars also revived Sunni Madhhab, making it the largest Muslim Madhhab in Egypt.

During his time, two new traditions were created, first preparing Kiswah for the Bait Allah in Mecca Al-Mukarramah and it was delivered with a ceremony in each season. Submission of Kiswah will become a prerogative right and would even be sanctioned in an agreement signed by Sharif Najm al-Din Muhammad Abu Nuwayy (ruling 652-701 / 1254-1301 AD) if he did not do so, although there were many wishes to did so, for example from the Rasulid, Ilkhanid who also sent kiswah from time to time to confirm their existence. Second, placing four Imams of the Madhhab (Maliki, Hanafi, Shafi'i, Hanbali) on the four corners of the Bait Allah. Both traditions were continued by Sulthan Qalawun and continued for centuries after his death.

\section{d. Manshur Syafrudin Qalawun al-Alfi}

Qalawun ruled after replacing Sultan al-'Adil Badruddin Salamisy who was in power for only one year. If Sultan Baybars was known as a military builder, then Qalawun was known as government administration and international trade network builder for Egypt. Sultan Qalawun put down a succession system or the appointment of a sultan based on heredity (monarchy). So, after his leadership, the power of the Mamluk Bahri Dynasty was in the hands of his descendants. The system often caused upheaval and dissatisfaction with the Mamluk family, because there were times when the appointed sultan was incompetent. Therefore, after the reign of Sultan Manshur, the government of the Mamluk Dynasty often experienced conflicts and power coups.

\section{e. An-Nashir Nashiruddin Muhammad bin Qalawun (696 AD/1296 AD)}

Nashir was the crown prince of Qalawun and held the reins of government three times, and had been demoted twice. The first time he ascended the throne in 693 $\mathrm{H} / 1293 \mathrm{AD}$ is when he was still nine years old, so he was overthrown by Amir Zainuddin Kitbugha. His authority was handed over to Manshur Lajin, and in $698 \mathrm{H} /$

\footnotetext{
${ }^{8}$ Denise Aigle, "Legitimizing A Low-Born, Regicide Monarch: The Case Of The Mamluk Sultan Baybars And The Ilkhans In The Thirteenth Century", 2006, h. 2.

${ }^{9}$ Didin Saefuddin Buchori, Sejarah politik Islam, Bandung: Pustaka Intermasa, 2009, h. 220.
} 
$1298 \mathrm{AD}$, he was re-appointed as sultan for the second time. However, in $707 \mathrm{AH} /$ $1308 \mathrm{AD}$, he was overthrown by his ambitious warlord, Baybars. A year after being overthrown, Nashir gathered strength and support from the emirs and his people so that in $708 \mathrm{H} / 1309 \mathrm{AD}$, he could regain his throne again. He was a wise sultan and loved by his people, and was in power for a long time. In 702 H / 1303 AD, He defeated the Tatars in a battle that took place near Damasykus.

\section{f. Azh-Zhahir Syafruddin Barquq (784/1382-801/1399 AD)}

Barquq was one of the slaves recruited by Sultan Qalawun to serve his family. When there was a conflict related to the succession of the empire, Barquq was a senior minister who served and became the guardian of the young sultan. The opportunity to control power was in his hands because he was the governor of Sultan Hajji. He consolidated his power so that he was truly ready to take power officially from the Sultan's hand. In $784 \mathrm{H} / 1382 \mathrm{AD}$, Barquq overthrew Sultan Hajji and appointed himself as sultan, and held the title Malik Dhahir Saifuddin Barquq. He acted nepotically, thus placing his family as an official to strengthen his position. Among his achievements, he was able to fortify Egypt from the invasion of Eastern Lenk's troops. Thus, the Mamluk Dynasty had become a strong fortress in protecting Egypt from twice the invasion of Mongol, Hulagu Khan and Timur Lenk

\section{Islamic Economy During the Mamluk Dynasty}

The Mamluk Dynasty was built on the strength of solidarity between them even though they were initially weak and oppressed. The majority of Mamluk rulers, in fact almost all of them were slaves of the sultan or even of slaves of the nobility. With high solidarity, they could form a very powerful alliance of forces, which with this power could create a great dynasty in the golden ink record of Islamic civilization.

The Mamluk Dynasty was established after the fall of the Abbasid Daula due to the invasion of the Mongols. The Mamluk Dynasty succeeded in becoming a savior of the grandeur and glory of Islamic civilization by giving birth to various advances in various fields of life, including the economic field. Although the Mamluk dynasty in the process faced three direct threats namely the Mongols, the Crusaders, and the Ottomans. But the Mamluk Sultans succeeded in creating prosperity and prosperity in society with a variety of appropriate and good economic policies. So that it could be felt by all levels of community life.

Thanks to the strong economy of the Mamluk Dynasty that was able to build beautiful and magnificent buildings. Many architects were brought to Egypt to build beautiful schools and mosques. Mosques were built with beautiful domes and towers. Beautiful mosaics in the arches of building's works of art and wood in the pulpit were quite complicated to make. Even Sultan Baybars - even though he was preoccupied with some wars - especially in dealing with European crusaders, he still had time to build important monuments in the form of mosques. 
In general, six main factors led to economic progress during the Mamluk Dynasty. First, the governmental system was a military oligarchy rather than a monarchy that build a sense of justice, solidarity, and professionalism among Mamluks. With this system, political costs and violence can be limited through the distribution of resources and rotation of power so it did not create any conflicts and power seizing. ${ }^{10}$ Thus, every sultan who governed could focus on developing the economy and be assisted by executive power which was run by an elite military group with four administrative institutions such as the diwan al-jaisy which dealt with military administrative and structuring issues, the diwan al-insya which dealt with administration and letters -district, diwan al-nazar which dealt with the state income and expenditure sector, and diwan al-ahbas which managed the area of representation in Egypt and Syria.

Second, the appreciation for scientists and academics. During the Mamluk dynasty, scientists and academics were paid directly from the palace. At that time, the professors of al-Azhar had gained a very respectable status in the dynamics of the scientific movement in Egypt. They were distinguished from lecturers and other instructors through forms of toga and academic degrees. Even the fatwa of a Shaykh alAzhar was able to influence the pattern of political policy and governance of the Mamluk Sultanate. ${ }^{11}$ It was this kind of policy that later made the Mamluk Dynasty both in Egypt and Syria experienced a golden age with intellectual prowess with various high-quality scientific works, especially in the field of Arabic encyclopedia literature. Famous figures were born such as Shihab al-Din Ahmad bin Abd al-Wahhab al-Nuwayri (d. 733/1333 AD), Fadl Allah al-'Umari (d. 749-1349 AD) and Ahmad bin Ali al-Qalqashandi (d 821/1418 AD) for his extensive work, a multi-theme collection that included thousands of pages, cosmologists, batoni, ethics, and zoology. ${ }^{12}$

Many scientists migrated from Baghdad to Egypt and made Egypt the center of new knowledge in the world. Prominent figures were born namely; Syamsuddin Ahmad ibn Muhammad ibn Khallikan or Ibn Khallikan with his famous work Wafayat al-A'yan wa Anba Abna Az-Zaman (the story of prominent people and the history of the pioneers of the Age). It contained about 658 biographies of prominent Islamic figures and this book became the first national biography dictionary in Arabic.

Abu Hasan Ali Nafis in the field of medicine made a major contribution to his work, Syarh Tasyrih al-Qanun, which explained a clear conception of the function of the lungs as a blood circulator. This work was even written two and a half centuries before the Spanish writer Servetus published his findings in the same field. Ibn Usaybi'ah with his work "Uyun al-Anba fi Thabaqat al-Atibba (Reference source about

${ }^{10}$ Lisa Blaydes, “Mamluks, Property Rights, and Economic Development: Lessons from Medieval Egypt", Politics E Society, Vol. 47(3), 2019, h. 400. DOI: 10.1177/0032329219861756

${ }^{11}$ Mohammad Thoha, "Politik Pendidikan Islam; Potret Sejarah Periode Klasik Sampai Abad Pertengahan", Tadris, Volume 8, Nomor 1, Juni 2013, hlm. 31-32.

12 Elias Ibrahim Muhanna, "Encyclopaedism in the Mamluk Period: The Composition of Shihāb al-Dīn al-Nuwayrī's (D. 1333) Nihāyat al-Arab fī Funūn al-Adab", Doctoral Dissertation, Harvard University, 2012, h. 10. 
the level of the Doctors). This book collected in detail and was completed with 400 biographies of Arab and Greek medical experts.

In the field of history, there were Abul Fida with his works Mukhtashar Date of al-Basyar and Ibn Taqhribardi wrote the work of an-Nujum Azh-Zhaharirah fi Muluk Mishr wa Qahirah Containing the history of Egypt from the conquest until 1453 AD. In the economic field, There was Taqi al-Din Ahmad ibn 'Ali ibn' Abd al-Qadir ibn Muhammad al-Maqrizi with his work Ighathat al-ummah bi-kashf al-ghummah,

Ibn Khaldun, the father of sociology and expert of history, law, philosophy, economics, geography, and other social sciences, also lived during the Mamluk Dynasty. Great works were born from him like al-I'bar wa Diwan al-Mubtada 'wa alKhabar fi al-A'yan wa al-'Arab wa al-'Ajam wa al-Barbar wa man' Asrahum min Zawi as- Sulthan al-Akbar, al-Muqadimmah book, At-Ta'rif bi Ibn Khaldun Mua'llif haza alKitab book, and Lubab al-Muhassal fi Usul ad-Din book.

In the field of religious studies, a versatile Imam was born, Imam Jalaluddin asSuyuthi had more than 500 scientific works produced such as Al-Itqaan fi 'Uluumil Qur'an, Taqriibul Ghariib, Mafaatihu al Ghaib fi at-Tafsiir, Ma Rawhu As-Salathin fi Adami Al-Maji ila As-Salathin, Al-Habaik fi Akhbar al-Malaik, Ad-Dar al -Mantsur fi at-Tafsir bil Ma'tsur, Ad-Dar al-Muntatsirah fi al-Ahadits al-Musytahirah, Ad-Dibaj 'ala Sahih Muslim bin al-Hajjaj, Ar-Raudh al-Aniq fi Fadhli ash-Sadiq, Al -'Urf al-Wardi fi Akhbari al-Mahdi, Al-Gharar fi Fadhaili 'Umar, and many others. Furthermore, Taqiyuddin Ahmad bin Taimiyyah or better known as Ibn Taimiyyah (1263-1328 AD), a leading ulama in religious thought. Ibn Taimiyah's essay reached three hundred volumes, including: Iqtifa al-Sirat al-Mustaqim wa Mukhlafah as-Hab al-Jalum, Fatawa Ibn Taimiyah, Al-Salim al-Maslul Al-Syatim al-Rasul, Al-Salim al-Maslul fi Bayan Wajibat Al-Ummah Nahwa Al-Rasul, al-Reply al-Sahih li Man Baddala Din Al-Masih, and a number of other books in the field of fiqh.

In the field of hadith, there was the famous Allamah, Ibn Hajar al-Asqalani (1372-1449 AD). His works such as Fathul Bari, Ad-Durar al-Kaminah, Tahdzib atTahdzib, Al-Ishabah fi Tamyiz ash-Shahabah, Bulughul Maram, Al-Isti'dad Liyaumil Mii'aad, and Nukhbatul Fikr. A mathematician named Abu Faraj bin al-Ibri, a literary expert named Syarafuddin Muhammad al-Busiri, and an observatory expert, Nashiruddin Ath-Thusi

Third, Establishing Trade Relations with foreign countries. The Mamluk Dynasty was an open dynasty to have cooperation with anyone in the economic field, in particular, they opened trade relations with various countries, including French and Italian Mediterranean Christians through an expansion of trade routes pioneered by the Fatimid Dynasty, despite the anti-Christian government policies. The Mamluk dynasty continued to make trade agreements with James I, in collaboration with Charles of Anjou, King of Sicily. The fall of Baghdad made Cairo the trade route between Asia and Europe more important because Cairo connected the trade routes of the Red Sea and the Mediterranean with Europe. ${ }^{13}$ This relation became one of the

${ }^{13}$ Dedi Supriyadi, Sejarah Peradaban......, h. 245. 
factors that caused Ibn Khaldun to be amazed by the progress of civilization that Cairo, Egypt during the Mamluk Dynasty had achieved.

Fourth, the free-market policy for farmers. The Mamluk Sultan gave a free market policy to the farmers, meaning that the farmers were given the freedom to market their agricultural products themselves and were supported by the construction of a transportation and communication network connected to various regions, thereby facilitating trade transactions and other needs. The Mamluk Sultans involved the military in fiscal administration policy by wanting to spend large funds to hire foreign military elites, to manage and control the assets of agricultural resources because part of the wealth of the empire came from rural areas. Thanks to this policy, the Sultan enjoyed the results of renting agricultural land in rich Egypt and the administration was managed with the sophistication of the bureaucracy so that there was a mutually supportive relationship between the agricultural community and the military and supported the progress of the Mamluk army and the government. By being involved with the military in administrative matters, allowing every possible threat of rebellion, intimidation of certain groups in the community could be quickly suppressed. In the event of protests from the public due to uncertainty about the Sultan's policy, there was an opportunity for the military to resolve the complaint or negotiate it so that an immediate solution could be found. ${ }^{14}$

Moreover, to eliminate monopolies in agriculture, Sultan Mamluk made a policy whereby the rich would not be able to make large investments in land, including those assigned to him, by reducing incentives for investment and preventing wealth holders from putting funds into agricultural maintenance, including the Amirs though. ${ }^{15}$

Fifth, Navy Resilience. The resilience of the Mamluk Dynasty navy fleet greatly assisted the development of its economy. Even at the time of Sultan Al-Ashraf Baribai (1422-1437 AD) and al-Zahir Khusyqadam (1461-1467 AD), the navy was not only able to defend its territory from Crusader attacks on the Cypriot and Rhodos Islands (Aegean Sea, Greece) but also to prove its superiority in controlling trade routes in the Mediterranean.

The challenges of the Mamluk dynasty in the maritime field came from the Portuguese who damaged the Egyptian economy. The Portuguese who arrived in the Indian Ocean became the main competitors in the spice trade. Portuguese navigators disrupted the flow of spices from Calicut to Egypt and looted a fleet of pilgrims to their Sea. They disrupted business contacts between India and the Far Eastern countries and the Mamluk region, Egypt, Syria, and Arabia. Not only did these attacks pose a serious threat to the Mamluk trade, but they also caused an increase in costs in protecting the trade. ${ }^{16}$

${ }^{14}$ Lisa Blaydes, "Mamluks, Property......", h. 401.

${ }^{15}$ Lisa Blaydes, "Mamluks, Property......", h. 413.

${ }^{16}$ Wan Kamal Mujani, "Some Notes on The Portuguese \& Frankish Pirates During The Mamluk Period (872-922AH. /1468-1517AD.)”, Malim: Jurnal Pengajian Umum Asia Tenggara, 8 December, 2016, h. 18. 
The next threat came from the pirates (robbers) of the French who had been continuously shipping goods in the Mediterranean since the middle of the twelfth century, starting from attacking and looting the cargo and ports of Mamluk. In reaction to this, the Sultan often arrested the French Consuls, and their merchants and goods, and was released if the pirates released their captives and sent back merchandise. This continuous attack by the Frankish pirates was one of the factors that weakened the economy of the Mamluk dynasty, especially in the 15th and early 16th centuries as attacks increased in the ports of Egypt and Sham and they captured Muslim traders and confiscated their belongings and some of the robbers who often attacked the coast of Egypt were from Catalonia, Cyprus, and Rhodes. ${ }^{17}$

Sixth, The effectiveness of waqf property use. Waqf was among the most effective economic tools during the Mamluk Dynasty. Whatever could be presented benefits may be represented as waqf. Agricultural land and buildings such as office buildings, lodging, and learning places were the biggest assets for waqf. Even that time, there was a waqf performed by slaves to look after the mosque and school. Waqf became a lifestyle and everyone tried to invest in waqf, which allowed themselves and their descendants to live safely without fearing that their assets would be taken over by the Sultan. ${ }^{18}$

The benefits of waqf during the Mamluk dynasty were used as the aims of waqf, such as family waqf for family interests, general waqf for social purposes, building a place to take care of the corpses and to help the needy and poor people. What further brings the symbol of Islam is the endowments for the means of Harmain, namely Mecca and Medina, like the Ka'bah cloth (kiswatul ka'bah). As King Shaleh bin al-Nasir, who bought the village of Bisus, was then committed to financing the Ka'bah mission every year and replaced the grave cloth of the Prophet and his pulpit every five years. The waqf law was formed during the time of Sultan al-Dzahir Bibers alBandaq (1260-1277 AD), whereby this law the Sultan elected judges from each of the four Sunni schools of law. ${ }^{19}$ Even during the time of Sultan Barquq who ruled 872-901 / 1468-1496 AD, waqf was made as one of the main components in the economic recovery effort by improving the system of legal property and improving the access of institutional waqf to state assets. ${ }^{20}$

\section{The Factors of Economic Decline and Mamluk Dynasty Collapse}

War, disease outbreaks, natural disasters, and economic crises were the main causes of the decline of the Mamluk Dynasty which had ruled for more than three centuries with various advancements achieved and the greatness of those who were able to defeat the Mongol troops, the Crusaders and survived with the Military

17 Wan Kamal Mujani, "Some notes on the....", h. 18.

${ }^{18}$ Lisa Blaydes, “Mamluks, Property......", h. 404.

${ }_{19}$ Djunaidi Ahmad dan Thobieb Al-Asyhar, Menuju Era Wakaf Produktif, Depok: Mumtaz Publishing, 2007. h. 50

${ }^{20}$ Bethany J. Walker, "Popular responses to mamluk fiscal reforms in Syria", Bulletin d'etudes orientales [Online], Tome LVIII I Septembre 2009, h. 54. DOI: 10.4000/beo.60 
Oligarchy system rather than Monarchy as the existed former dynasties system. Below will be explained some of the factors that influenced the decline of the Mamluk Dynasty, namely:

\section{a. Economy Crisis}

During the Mamluk dynasty, there was often instability in the monetary system which ended in an economic crisis. As a consequence, it gave a bad effect on people's purchasing power and economic activities, ranging from borrowing, saving and investment, trade, production and consumption, exchange and distribution, etc. Social class was divided into two parties in power and people could suffer. The authorities tried to restore resources by suppressing regressive taxes, monopolizing business and food stockpiling, which led to an increase of farmers and small workers' miserable

A large amount of fulus in circulation and the increasing amount of copper in the dirham currency affect the instability of the monetary system. At that time, three types of money were circulating, dinars (gold), dirhams (silver), and fulus (copper). The Circulation of the dinar was very limited, the circulation of dirhams fluctuated, it sometimes even disappears, while the wide circulation is fulus. So that it caused lowquality money (fulus) that would kick out the high-quality money (dinar, dirham). ${ }^{21}$ Even in the reign of Adil Kitbugh and Sultan al-Zahir Barquq and his son Faraj, copper coins became the main currency and printing dirhams were stopped which resulted in a decrease in the value of currencies and scarcity of goods on the market.

The printing of copper coins became the main currency that occurred for several reasons. First, because of the sale of silver to European countries. Second, an increase in copper imports from European countries due to the increased production of mining in the majority of European regions. Third, more silver was used as raw material for the manufacture of saddles and vessels. ${ }^{22}$

This act was, of course, detrimental to people who had money, because of the fall of the old currency into ordinary merchandise. It means the government was acting wrongfully to them by eliminating the true high value they had. Moreover, if the intrinsic value of the coin was different, it could be a source of profit for someone to collect a worse coin currency and exchange it (for a more valuable currency) and then took it to another country to exchange for another worse value coin to be brought to his country. So, as a result (the value of) goods belonging to the population would be destroyed. For this reason, Ibn Taimiyyah who lived during the Mamluk Dynasty asked the Sultan to examine the causes of monetary instability that caused economic turmoil and suggested that the Sultan re-print coins (gold and silver) according to the fair transaction value of the population, without the involvement of tyranny on it. ${ }^{23}$

${ }^{21}$ Adiwarman A. Karim, Ekonomi Islam; Suatu Kajian Kontemporer, Jakarta: Gema Insani Press, 2001, h. 59.

${ }^{22}$ Amir Machmud, Ekonomi Islam; Untuk Dunia Yang Lebih Baik, Jakarta: Salemba Empat, 2017, h. 100.

${ }^{23}$ Abdul Azim Islahi, "Economic and Financial Crises in Fifteenth-Century Egypt: Lessons From the History", Islamic Economic Studies, Vol. 21, No. 2, November, 2013, h. 75. 
The strongest criticism came from al-Maqrizi especially against the fiscal policy carried out by the Mamluk Dynasty in its treatise on needing (Ighathat al-ummah bikashf al-ghummah). The strongest criticism came from al-Maqrizi especially against the fiscal policy carried out by the Mamluk Dynasty in its treatise on hunger (Ighathat al-ummah bi-kashf al-ghummah). Al-Maqrizi captured the reality of life for most of Cairene at the turn of the fifteenth century, where people were starving, and food, although available, was not well distributed. as a result, food scarcity resulted in increasing prices and buyers were forced to buy, bribery was done, taxes were high, and the currency was unstable, Whereas the monetary policies adopted by the Bani Mamluk Burji government did not provide a solution for the improvement of the people's economy but in contrast, it became the disaster source in destroying the State economy and the people of Egypt. ${ }^{24}$ Inflation continued to increase and accelerate the destruction of the Mamluk Dynasty.

While the advice mentioned by Muhammad Ibn Khalil al-Asadi, in his work on administrative and financial reforms (al-Taysir wa al-i'tibar wa al-tahrir wa al-ikhtibar fi-ma yajibu min husn al-tadbir wa altasarruf wa al-ikhtiyar ) written around 854.1450 $\mathrm{AD}$ According to him, the economic revival required decisive action from the government. The government's responsibility was to control currency values, ensured unlimited markets, and ensured the availability of basic foodstuffs. ${ }^{25}$

\section{b. The Rulers' Lifestyle}

The lifestyle of the rulers contributed greatly to the economic downturn of the Mamluk Dynasty. Sultan Nashir, during his reign, enjoyed a lively lifestyle and squandered wealth. When holding his son's wedding feast, he served 18,000 slices of bread, slaughtered 20,000 cattle, and lit 3,000 candles to light up his palace, spending a lot of money on personal pleasures such as horse riding. Even Nashir once issued 30,000 dinars, for the sake of a horse he liked. For the sake of satisfying a high lifestyle, Nashir did not hesitate to impose a refractive tax that was not accountable to the people, so that it is counter-productive to the people. As a result, many protests and criticisms mandated to him that led to the collapse of the Mamluk Bahri Dynasty. ${ }^{26}$

\section{c. Corruption and Economic Monopoly}

Corruption and economic monopoly were carried out by the sultans in managing the development. Sultan al-Aziz Yusuf bin Barsibai banned imports of spices from India even though the Mamluk Dynasty was a much-needed importer of pepper. Before the price rose, he monopolized the existing stock of spices and then sold it to consumers with very high pepper. He also monopolized sugar and went further by

\footnotetext{
${ }^{24}$ Ambok Pangiuk, "Inflasi pada Fenomena Sosial Ekonomi: Pandangan Al- Maqrizi", Kontekstualita, Vol. 30, No. 2, 2015, h. 227.

${ }^{25}$ Bethany J. Walker, “Popular responses to mamluk....", h. 53.

${ }^{26}$ Dedi Supriyadi, Sejarah Peradaban......., h. 247.
} 
banning sugarcane for a period to gain huge profits. ${ }^{27}$ When the government conducted a monopoly and policies to prohibit the production of sugar/sweets by other parties would result in a reduction in overall sugar production which resulted in high commodity prices, and ultimately added to the burden of people who were in direct contact with the industry including its workers. The indirect effect of monopoly was the damage appearance which was seen in the domestic and foreign trade of the Mamluk dynasty. Domestic traders could not sell their commodities to outside importers or buyers from outside Egypt, such as traders from the Mawsil, Hamah, and Damascus regions. ${ }^{28}$

Monopolizing also applied to other sectors, namely agricultural land. The ownership of agricultural land was centralized for economic benefits in the hands of the Sultan, except for certain lands in the form of waqf and one kind. Only a small portion was controlled by the private sector and traded which were initially sold from Bayt al-Mal. The management was not directly carried out by the government but was carried out by other parties with certain systems, namely iltizam/tadmin, and iqta'. In addition to land tenure, Mamluk dynasty government officials also increased the price of renting agricultural land to farmers up to ten times..$^{29}$

The direct impact of the Mamluk Sultan monopoly on the economy was that economic freedom was bound by the Sultan's decisions that wanted a large level of profit to cover the budget deficit. However, these authoritative decisions and actions had negative implications for the economy, where prices in the market surged. The indirect effect of monopoly was the appearance of considerable damage to domestic and foreign trade. Domestic traders could not sell their commodities to outside importers or buyers from outside Egypt. ${ }^{30}$

Corruption and bribery also thrived especially in economic activities in the market. The scope of Hisbah (market watchdog) was broadened to include the proper duties and functions and an office was provided for a muhtasib (person in charge of hisbah). However, because of the large-scale corruption in the government and its institutions, the role of muhtasib was often misused especially in filling muhtasib's position by giving bribes to the position. Even sometimes muhtasib accepted supa so he did not carry out its main task in checking prices on the market, resulting in illicit marketing and a lack of staples. The Sultan resolved it by providing subsidies and rationing. Even though all this was caused by an error from the administration of bad prices due to the inability of hisbah and muhtasib. ${ }^{31}$

Monopolistic practices and the use of high taxes during the reign of Sultan alAshraf Barsbay (826-842 H / 1422-1438 AD) and his successor became a factor for Europeans to search for and mobilize all waterways to East Asia. Whereat the end of

${ }^{27}$ Dedi Supriyadi, Sejarah Peradaban........, h. 247.

${ }^{28}$ Aidil Novia, "Kajian Intervensi Harga oleh Pemerintah Dalam Pemikiran Al-Maqrizi”, Peneliti Madya,Padang : IAIN Imam Bonjol, 2009, h. 9

${ }^{29}$ Aidil Novia, "Kajian Intervensi Harga...........", h. 10.

${ }^{30}$ Aidil Novia, "Kajian Intervensi Harga............", h. 14.

${ }^{31}$ Abdul Azim Islahi, "Economic and Financial...", h. 77. 
the fifteenth century, the Portuguese government had taken the lead in searching for a new route to India and Vasco Da Gama discovered a new route to India and the Far East through the Cape of Good Hope in South Africa. Their main objective was to control the spice trade by occupying strategic ports and harbors and arranging navigation in the Indian Ocean. ${ }^{32}$

\section{d. The Attack of Other Nations}

The attack on the Mamluk Dynasty was not only originated from the inside but also the outside. The attack from the outside came from the Ottoman Turks, Crusaders, the Portuguese who banned and harassed the Mamluk trade routes in the Mediterranean Sea as well as the longtime enemy of the Mongol army who wanted to regain control of the territories of the Mamluk Dynasty. As a result, many Mamluks were preoccupied with dealing with attacks that occurred, rather than managing the economy of the empire and the people. Even the Sultanate funds which should be devoted to the welfare of the community were spent a lot for military purposes, while the income was running low. War after war with various nations accelerated the economic decline in central and surrounding Arab lands.

\section{e. The Sultan's Bad Behavior}

Philip K. Hitti stated that the most dominant factor weakening the position of the Mamluk Dynasty was the bad behavior of the sultans such as deception, murder, slaughter, cruel, fraudulent, and immoral behavior. For example, Sultan al-Muzhaffar Ahmad Ibn Al-Muayyid (1412-1421 AD) was a drunkard, committing various heinous acts that exceeded the limits. Sultan Barsibai (1422-1438 AD) beheaded two of his doctors because he could not cure him of a severe illness. Sultan Inal (1453-1460 AD), could not read and write, did not even memorize the first letter of the Qur'an. ${ }^{33}$

The behavior of the Mamluk (Burji) rulers who diverged greatly from religious and moral teachings had resulted in a severe economic crisis dominated by inflationary trends which were further exacerbated by the outbreak of infectious diseases that plagued Egypt for some time. The situation inspired Al-Maqrizi to present his views on the causes of the crisis in his work Ighatsah Al-Ummah bi Kasyfil Gummah (Helping the Ummah by Curing the Cause of the Crisis). ${ }^{34}$

\section{CONCLUSION}

From the previous explanation, it can be concluded that the Mamluk dynasty had several sultans who had enormous influence such as Aybak or Izuddin Aybak bin Abdullah Shalihi, Al-Muzhaffar Syafruddin Qutuz, Muhammad Ruknuddin Baybars,

\footnotetext{
32 Wan Kamal Mujani, "Some notes on the h. 19.

${ }^{3}$ Philip K. Hitti,History of The Arab, London: The Mac Millan Press, 1974, h. 680-695.

${ }^{34}$ Ambok Pangiuk, “Inflasi pada Fenomena........, h. 227.
} 
Manshur Syafrudin Qalawun al-Alfi, An-Nashir Nashiruddin Muhammad bin Qalawun, and Azh-Zhahir Syafruddin Barquq. These important policies of the Sultans made the economy of the Mamluk dynasty progress as the governmental system was a military oligarchy rather than a monarchy which made the rise of a sense of justice, solidarity, and professionalism among the Mamluks. Appreciating scholars and academics and even their fatwas could influence the Sultan's policy. The Mamluk sultans established trade relations with foreign countries, especially in the fields of exports and imports, implemented a free market policy for farmers, built a strong navy to guard economic and political interests, and made effective use of waqf property. While the economic setbacks of the Mamluk dynasty were largely motivated by the economic crisis, the bad lifestyles of the sultans, corruption and trade monopolies, attacks by other nations, and the bad behavior of the Sultan.

\section{E. REFERENCES}

Ahmad, Djunaidi, Thobieb Al-Asyhar, 2007. Menuju Era Wakaf Produktif, Depok: Mumtaz Publishing.

Aigle, Denise, 2013. "Legitimizing A Low-Born, Regicide Monarch: The Case of The Mamluk Sultan Baybars and The Ilkhans in The Thirteenth Century", Abstracta Iranica, Volume 32-33, 2013.

Aji, A.M.; Yunus, N.R. Basic Theory of Law and Justice, Jakarta: Jurisprudence Institute, 2018.

Aravik, Havis, 2017. Sejarah Pemikiran Ekonomi Islam Kontemporer, Depok: Kencana.

Blaydes, Lisa, 2019. “Mamluks, Property Rights, and Economic Development: Lessons from Medieval Egypt", Politics \& Society, Vol. 47(3), 2019, h. 400. DOI: $10.1177 / 0032329219861756$

Buchori, Didin Saefuddin, 2009. Sejarah politik Islam, Bandung: Pustaka Intermasa.

Dekkiche, Malika, 2015. "New Source, New Debate: Re-evaluation of the MamlukTimurid Struggle for Religious Supremacy in the Hijaz (Paris, BnF MS ar. 4440)", The Middle East Documentation Center (Medoc), 2015, h. 248. DOI: 10.6082/M1JD4TXG

Hitti, Philip K., 1974. History of The Arab, London: The Mac Millan Press.

Islahi, Abdul Azim, 2013. "Economic and Financial Crises in Fifteenth-Century Egypt: Lessons from the History", Islamic Economic Studies, Vol. 21, No. 2, November 2013.

Karim, Adiwarman A., 2001. Ekonomi Islam; Suatu Kajian Kontemporer, Jakarta: Gema Insani Press.

Machmud, Amir, 2017. Ekonomi Islam; Untuk Dunia Yang Lebih Baik, Jakarta: Salemba Empat. 
Maggalatung, A.S.; Aji, A.M.; Yunus, N.R. How The Law Works, Jakarta: Jurisprudence Institute, 2014.

Manshur, Fadlil Munawwar, 2008. “Dinasti Mamluk dan Perang Salib; Perspektif Historis", Seminar Internasional Tentang Timur Tengah, Universitas Gadjah Mada, Keluarga Alumni Gadjah Mada (Kagama) dan Departemen Luar Negeri Republik Indonesia, Yogyakarta, 25-26 Maret 2008.

Muhanna, Elias Ibrahim, 2012. "Encyclopaedism in the Mamluk Period: The Composition of Shihāb al-Dīn al-Nuwayrī's (D. 1333) Nihāyat al-Arab fī Funūn al-Adab", Doctoral Dissertation, Harvard University, 2012.

Mujani, Wan Kamal, 2016. "Some Notes on The Portuguese \& Frankish Pirates During The Mamluk Period (872-922AH./1468-1517AD.)", Malim: Jurnal Pengajian Umum Asia Tenggara, 8 December, 2016.

Novia, Aidil, 2009. "Kajian Intervensi Harga oleh Pemerintah Dalam Pemikiran AlMaqrizi", Peneliti Madya,Padang : IAIN Imam Bonjol, 2009.

Pangiuk, Ambok, 2015. "Inflasi pada Fenomena Sosial Ekonomi: Pandangan AlMaqrizi", Kontekstualita, Vol. 30, No. 2, 2015.

Supriyadi, Dedi, 2008. Sejarah Peradaban Islam, Bandung: Pustaka Setia.

Thoha, Mohammad, 2013. "Politik Pendidikan Islam; Potret Sejarah Periode Klasik Sampai Abad Pertengahan", Tadris, Volume 8, Nomor 1, Juni 2013.

Walker, Bethany J., 2009. "Popular responses to mamluk fiscal reforms in Syria", Bulletin d'etudes orientales [Online], Tome LVIII I Septembre 2009, h. 54. DOI : 10.4000/beo.60

Yunus, N.R.; Anggraeni, RR Dewi.; Rezki, Annissa. "The Application of Legal Policy Theory and its relationship with Rechtsidee Theory to realize Welfare State," 'Adalah, Volume 3, No. 1 (2019)

Zamzam, Fakhry \& Aravik. H., 2019. Perekonomian Islam; Sejarah dan Pemikiran, Depok: Kencana. 